\title{
REGIONAL DEVELOPMENT SUSTAINABILITY ANALYSIS CONCEPT
}

\author{
Janno Reiljan ${ }^{1}$ \\ TÜ majandusteaduskond
}

\begin{abstract}
Problems associated with the qualitative analysis and quantitative measurement of sustainability, and opportunities for connecting the concept with the methodological basis of development assessment and the essence of the subject that values sustainability are dealed. The goal of article is to work out the basics for analysis of the regional development in a country in terms and framework of sustainability concept. The article starts by outlining the definition of sustainability, which is followed by an analysis of the nature of sustainability. The third subsection highlights the demands of the decision-making process in guaranteeing sustainability and then considers sustainability in a competitive environment. In the second part of article the sustainable development conception is implemented in regional development sustainability analysis.
\end{abstract}

Key words: sustainability, sustainable development, regional development

JEL-classification: O18, R10

\section{Introduction}

In the process of pursuing a scholarly understanding of the world and society, we sometimes reach a point where new problems and our newly accumulated understanding force us to a new paradigm in order to generalize. When creating such a new paradigm in recent decades, the central keyword has been sustainability.

A term like sustainability that is used so widely and in such a general sense, and also the paradigms connected to that word, can have such different meanings in different fields. Taylor (2002) notes in his overview that different authors have presented more than 70 definitions of sustainability. According to others (Moffatt et al. 2001:4) there are even more than 100 definitions. This is understandable because there is not and cannot be one single definition of "positive development" that satisfies all fields and every context. The diversity and even contradiction within sustainability concepts stems from discrepancies inherent within the development process.

These discrepancies cannot be resolved with an "easy ideological principle: development is how to make human life better. It is dependant on people and how they define this better life for themselves, their priorities in an objective system and

${ }^{1}$ Prof. Dr. Janno Reiljan, University of Tartu, EST-50090 Tartu (janno.reiljan@ut.ee) 
how to achieve them" (Soubbotina, 2004: 2). Different views of development come from different starting points and the different resources used, but also from the variety of subjective values. Using the variety of ideas derived from objective causes, it is necessary to create a specific approach to sustainable development in each different field. (Christen, Schmidt 2012)

The sustainability concept has not been fully developed (see Moffatt et al. 2001: 115; Pezzey et al. 2002; Taylor, 2002; Tafel, 2003). Moreover, when researching the activities of international organisations, scientists have come to the conclusion that the innovativeness of sustainable development goals and programs tends to be of a more terminological than conceptual nature (Barrachlough, 2001: IV). This means that in order to research, assess and manage sustainability in a specific field, there are no generally recognized and accepted presumptions, methodologies or indicators. They must be found every time, taking into account the theoretical and practical experience already accumulated from the research of sustainability in different fields.

According to the aim of this article - to work out the basics for analysis of the regional development in a country in terms and framework of sustainability concept - the following research tasks are tackled: in the first section creating a theoretical framework for analysing sustainability, taking into account socioeconomic indicators that describe the stages and dynamics of development. The second section the implementing of sustainability development concept in regional development sustainability analysis.

\section{Theoretical and methodological basics of the sustainability analysis}

\subsection{Defining sustainability}

The definition of sustainability emerged as a result of the extensive development of society (mainly the economy) and the worsening of ecological problems caused by wasteful consumption, suggesting that the potential for the natural environment to support human activity is increasingly questionable. The main threats to the sustainability of the natural environment were highlighted as the over exploitation of resources and wastefulness resulting in rapid depletion, the deterioration of the living environment in connection with the emission of pollutants exceeding their absorption, climatic changes resulting from human activities and the disappearance of natural diversity due to the extinction of plant and animal species. International work has primarily focused on generalising the world's ecological problems, and results have been achieved via the signing of conventions (see for instance NGLS Handbook ... 2000: 341-364). That is why the term sustainability was at first used to describe maximal durability of ecological groupings or associations, and their preservation for future generations with the help of organised and targeted preventive and protective activities. The ecological problems suggest the need to reevaluate the relationships between man and nature, and the new concept derived from that is sustainability. 
As with ecological associations, any increase in openness of range causes it to weaken and fade (e.g. globalisation), and due to human activities many formerly relatively isolated social, cultural, political and economic associations have weakened and disappeared. Beside positive changes some phenomena and tendencies appear in the development of society, which can be classified as detrimental to society. Mankind is not only careless with the natural environment, but also with created social, cultural and other values. The normal careless attitude towards old values when seeking and creating something new, but also the preference for traditional over new finally damages the potential for people (society) to develop. In culture, the social sphere, politics and economics the need to reevaluate mankind (society) and its living environment is increasingly relevant. That is why the relatively rapid emergence of the sustainability paradigm in different developmental fields is understandable.

The popularity of the term sustainability can be derived from the counter reaction to the increasing speed of life, to the flood of rapid changes around us. Under the circumstances of such rapid change, the desire to see something stable in society also becomes stronger, so people can understand themselves better in space (in all subsystems of society) and in time (in the short and long term).

The use of the term sustainability has sense only in connection with the conscious normative action of people in planning and directing the development of some association. Mankind does not only adapt to the environment, but by conscious targeted activities tries to change itself and the environment in order to strengthen its existence. The perception of the sustainability (or unsustainability) of development basically means giving value to those changes from the viewpoint of some subject. In such a case, the term development sustainability is in line with terms like: democracy, freedom and social justice (The politics of sustainable ... 1997: 7). Guaranteeing development sustainability means protecting life which demands that we respect life, justice (including economic), tolerance and the love of truth and equality (On the Way ... 1997: 20).

Values make the term sustainability subjective. Barry and Baxter (2004: 3) believe that the sustainability concept does not involve a material, but a spiritual approach to development problems. Moreover, the world's approach to sustainability should in their opinion be considered more religious than scientific. That would basically mean a strengthening of the anthropocentrism in our approach to sustainability, because unlike spirituality, it is difficult to attribute religiousness to natural associations beyond man. The potential for bringing the ecocentric approach and religion and philosophy together are viewed by Sessions (1995: 156-157).

In connection with development, the term sustainability becomes relative ${ }^{1}$. The boundaries between maintaining the quality (or nature) of the association and its

\footnotetext{
${ }^{1}$ Herewith development sustainability is not viewed in connection with concrete aspect, in which according to narrow approach there is understood preserving the quality (improvement)
} 
transition (or development) to a new quality are vague. The disappearance of existing associations helps and opens up the path to new associations. In many cases, the formation of the new without the disappearance of the old is not possible. Development means a continuous line of changes in existing associations. "Sustainable development encompasses economic, social, and ecological perspectives of conservation and change." (Afgan 2011: 448)

The more rapid the development the greater the risk of being unable to preserve the characteristics that are of interest to people in existing associations. From a static point of view, the development of a specific association is in direct opposition to sustainability - change means the disappearance of certain characteristics and components. From a dynamic point of view development can even be the basis for sustainability - making adjustments under new conditions in a changed form ensures the preservation of the essence of the association.

Sustainability can only be viewed from the dynamic point of view because the survival of the association is described or assessed within a changing contextual system (time). The author of the current study finds that sustainability (sustainable development) means positive changes in respect to the future of an association to guarantee its long-term survival (strengthening).

The changes influencing (strengthening or threatening) the existence of an association can be internal, but also from external factors (derived from changes in the environment). That is why it is suitable to consider the internal and external sustainability of an association separately in order to consciously create sustainability from the viewpoint of developing strategies. Internal (external) sustainable development means changes in the association (in the environment influencing the association), which ensuring the long-term stable existence or strengthening of that environment.

\subsection{Analysis of the nature of sustainability}

The question of a subject that provides an assessment of sustainability is undoubtedly intellectually interesting. From animating animals-birds it is often assumed that even stones and trees can be animate. Still the spirituality of natural associations and everything connected to their values is irrelevant in the sense of the sustainability paradigm. Let us start from the methodological problem that each subject will provide its own evaluation of past, current and future changes and will act according to that evaluation to guarantee sustainability within the limits of its resources. In this respect it is not important if man reserves spirituality for himself and leaves his insensible part to nature (Tüür, 2000: 13), or man that believes in the

of human ecological environment and in wider approach problems connected with health, education and social wealthware improvement are added (The politics of sustainable ... 1997: 6; Dempsey et al. 2011), but it is also important to preserve the historical remembrances (Rahnama, Yazdanfar 2014). 
spirituality of a stone, tree or animal. Each subject assesses its development and sustainability in its own interests taking into account its knowledge and ethical views and also acts within the limits of its resources when guaranteeing this sustainability. Delivering spirituality to a certain subject is not necessarily evidence of a good attitude towards that subject or of having treated that subject well. This is well proven by the actions of men against each other while presenting and protecting their own interests, which goes so far as to even include oppressing, attacking and destroying each other. When arranging relationships with other subjects, we are not directed so much by our evaluation of our communication partner, but by our evaluation of the (expected) gains-losses from those relationships, seen from the widest viewpoint.

Methodologically there is no basis for assuming that the assessment of the sustainability of the development in other associations about any subject or actions derived from that would emerge differently from the above. Spiritualising trees, berries, mushrooms or quarry is not an essential presumption for using the sustainability concept in forestry or hunting. The functioning of nature is normally not determined by such values as right and justice - these are a construct created by mankind. Even if we do not consider everything outside mankind as a subject (that means man takes into account only its interests when communicating to the outside world), the sustainable development concept is internally contradictory due to its subjectivity.

Therefore, subjectivity is viewed in connection with two approaches to sustainability, between which all previous attempts at defining the term can be divided as "strict" or "soft" (Taylor, 2002: 2; Bartelmus, 2000: 360; Barry, Baxter, 2004: 2; Williams, Millington, 200X: 4):

General guaranteeing of sustainability in the "strict" sense means conscious systematic action to protect or support as lengthy an existence as possible for all existing associations. Such action directed at minimising changes would result in halting all development, as when preserving all existence there is no space or resources for anything new. That is why the "strict" approach to sustainability is contradictory to the need to achieve revolutionary changes in the growth of human standards of living, improving their economic and social situation. Such a dogmatic approach is contradictory to developmental needs and does not find public acceptance.

- Problems arise when the "strict" sustainability concept is implemented for certain chosen associations. Who should choose preserved or supported associations and according to which concept? Each choice influences the welfare of social subjects differently, and that is why the attitude towards choice is in many cases different and even contradictory. Moreover, selective implementation of the "strict" sustainability concept means a transition to the "soft" concept, because the above demands the preservation of associations so far, as their usage does not bring any benefit to society. 
- According to the "soft" concept of sustainability, the disappearance of some associations can be accepted, but only when the associations forming instead of them increase the wellbeing of the society. Wellbeing is not an unambiguous and measurable phenomenon. Even the assessment of one narrow aspect of wellbeing economic wealth - is difficult, as many associations lack an economic co-measure (i.e. market price). The assessment of development sustainability is more difficult when wellbeing is considered in the broader sense than economic wealth - taking into account the aspects of natural, social, cultural and political living environment, but also human satisfaction with life and social position. Even if we assume it is possible to determine overall wellbeing qualitatively and a quantitative measurement method exists, then this often takes us back to problems derived from the different interests of the subjects involved. The special interests of single subjects and the private law protecting them do not recognise any superior concept for increasing general wellbeing that covers all of mankind. It is impossible to objectively determine a societal wellbeing that connects or generalises the wellbeing of all subjects, as society is composed of the same subjects with contradictory interests.

That is why sustainability concepts so far reveal the concern that those promoting them have for (value) developments in the natural environment or in society and their good will to avoid possible negative changes in the future. Still different subjects see problems and their possible solutions differently in terms of their own interests or values. That is why it is understandable that the term "sustainability" is viewed differently depending on context or level of generalisation, but also depending on the subject's approach. No right or single and complete assessment of sustainability can be formed due to the discrepancy between the interests of the subjects involved. Still it is sensible to work towards improving and unifying a methodological basis of development sustainability analysis and assessment.

To oppose the dominating social paradigm (DSP) in favour of the new environmental paradigm $(N E P)$ is unjustified (see Tafel 2003: 149) ${ }^{1}$. Such an approach to the problem, which is unilaterally prone to economic profit and demands constant growth of production and consumption, is careless when it comes to the natural environment. In sustainable development concepts, economic growth is no more equated with societal development, which was previously considered normal (Becker et al. 1997: 10).

So far there is no complete efficient system that would spare the natural environment from overly burdensome and senseless consumption or from the advertising that encourages consumption - practically there is no interest in such a system at all. Difficulties with ratifying the Kyoto protocol, accepting national waste laws and establishing "ecological taxes" confirm the domination of economic communities in the world's development concept. The interests of economic groups

1 Richardson views sustainbale development problems by parallelling antropocentric and biocentric (The politics of sustainable ... 1997: 44-48). 
do not only dominate above the natural environment, but also above the social sphere, the cultural environment and political life. Regardless of economic growth, "development decades" in the world brought with them worldwide debt crises, increasing poverty, uncontrollable population growth and environmental problems (On the Way ... 1997: 25).

Therefore, the problem is not in the dominance of anthropocentric ideology (Deep Ecology ... 1995) and when by guaranteeing the sustainability of development, man and nature will no longer be in opposition. The problem is in the despotic power of economic interests above all other societal subsystems and nature. Still the only justification of economic activities is serving human (development) needs, which incidentally can also assume the (sustainable) use of natural resources and consider man as part of economic processes (labour). When guaranteeing development sustainability it is necessary to change the current economy-centred development strategy against the human-centred (see Annist et al. 2000: 54), subjecting economic activities to the need to guarantee human development (includes both, development of individual and societal relationships) sustainability.

The dominance of economic interests in approaches to development is best illustrated by the circumstances in the UN that ordered and published the World Commission of Environment and Development (Brundtland Commission) report, "Our common future" (The World Commission ... 1987), where the term sustainable development ${ }^{1}$ was widely used for the first time, and according to Taylor (2002: 2) refers narrowly to the development path of expanding the economic wealth of mankind. Of course social, cultural, political and psychological wealth could also be viewed here, but the interest in measuring levels of development and dynamics inevitably shifts material values into the foreground because they can be better quantified.

For instance, methodology to asses the sustainability of countries developed by the World Bank (see Nõmmann et al. 2002) is directly and fully economy-centred, where the aim is to achieve capital growth and beside nature, man is valued only as an input in economic processes (natural and human capital) (Sustainable Development 2002: 2). That is why growth in economic, social and natural capital is directly classified under the concept of economic sustainability along side concepts based on economic productivity indicators (for instance man's average level of consumption) (see Moffatt et al. 2001: 75).

The continually dominant economy-centred approach in development concepts tries to hide its nature behind the new terminology. That is why we can appreciate the assessment, according to which the sustainable world approach is one of the most cunning and manipulable approaches of the last decades (Pravdic, 2002: 95).

\footnotetext{
${ }^{1}$ Sustainable is development path, which satisfies the needs and strives of current generation, not endangering same interests of future generations.
} 
The precise definition of problematic relations in development processes (economynature; society-nature; economy-society) is important for understanding the nature of misdevelopments and to develop solutions. Surely the over emphasising of economy-centred development sustainability will cause problems. But at the same time, real solutions are not being offered by any other approach over emphasising other fields. For instance, the ecocentric proposals of guaranteeing development sustainability (see Pelstring, 1997a: 2; Pelstring, 1999: 2) - constraining industrialisation, equal rates of growth in the economy and population (steady-state economy), preservation of natural resources, control over the number of people etc. are not applicable in practice because of the objective and impassable discrepancies in the interests of different subjects.

The main contradiction in the ecocentric approach to development sustainability comes from the different levels of development in different international regions, countries and domestic regions. The author of the current study supports the view, according to which differentiation of economic growth and use of natural resources cannot be viewed in the same way when considering the development problems of the poorest nations (electricity consumption per capita $80 \mathrm{kWh}$ annually) and richest nations (electricity consumption per capita $8000 \mathrm{kWh}$ annually) (see Sustainable Development ... 2001: 10-11). Every individual has the right to a healthy and full life (to the same extent as others) (Wiman, 2000: 30-32). It is difficult to demand that the present generation, whose needs are not fulfilled, limit its economic growth in the name of future generations (Soubbotina, 2004: 32). Even in richer countries, the basic needs of people for food, water, clothes and a place to live are not fulfilled, let alone the no less important higher level needs for employment, care for each other and health (Moffatt et al 2002: 2). We can only talk about such limits concerning subjects at the higher levels of consumption, because there is no option and right to ban the stragglers from striving for the level of those ahead of them. Radical ecocentrism would mean:

* constraining consumption in countries (regions) with higher wellbeing, until the countries (regions) on a lower level reach the same point;

* constraining income and consumption in wealthier parts of society, so that consumption among poorer people would reach the same level;

* the option of demanding the constraint of industrialisation in countries, where the industrial production per capita is on a higher level, allowing new investments and jobs in less industrialised regions;

* establishing limits on the use of natural resources in countries where the per capita usage is at a higher level than the average, and accepting usage growth in countries with lower development;

* establishing obligatory restrictions concerning the mining of natural resources in countries where they are present in abundance, so that global access to these resources would last longer.

The above radical ecocentric goals are not acceptable - not only economically, but also socially, politically and psychologically. Such ideas at closer inspection are emotional slogans without real power or mechanisms for execution, and in terms of 
the global achievement of interests, there is no subject with the necessary power. Moving towards ecological limits is possible to the extent that highly developed countries agree upon them and compensate countries with a lower level of development for the economic loss resulting from these restrictions.

Tafel and Terk's attempt to develop a human-centred sustainability concept to a balance-centred approach (Tafel, Terk 2003: 152-153) is interesting. According to Oja (1999: 9-10), an ethical measure will be added to any human-centred sustainability concept - man must in his activities be ethical towards all and everybody existing on planet earth (but why not the whole universe?). In the sustainable development concept, ethical is presented as a fourth dimension beside economical, social and ecological from the very beginning - in the world congress of environmental sustainability in Rio de Janeiro, 27 ethical principles to be followed were highlighted (Moffatt et al. 2001: 3-6). Ethical would involve a careful and foreseeing, sympathetic and responsible, sparing, equal and fair attitude. The new ethical attitude would then contrast to the old and less ethical.

When adding the ethical measure, the result is a human-centred development approach, against which people seemingly step. Ethics does not exist outside man; ethics is a social phenomenon. Ethics originates from and changes with society and that is why it has always been one principle of a human-centred approach, although with a different nature and span over time. Ethics as a principle of attitude towards some phenomenon is a part of aspects connected with development sustainability methodology (how balancing is achieved?), rather than a part of sustainability specification (what is balanced?).

To become free of idealistic interests, one must admit that the human approach to development problems is inevitably human-centred. Leaving aside the discrepancies of different human associations as a separate problem, mankind must take into account different fields to find the best solution to its development problems (see Tafel 2003: 154): individual, social system, cultural environment, social institutions, system of political relationships, economy, natural resources and natural environment. When positioning some specific field in the central point of an approach to development in the light of differently understandable terms of sustainability, one can attract attention to the underestimating of that specific field or misunderstanding of it in current development approaches. But such fragmentation cannot be the basis for a more ideal development concept. That is why it would be wrong to state that with the emergence of the development sustainability problem, some totally new abnormalities in human action or measures for preventing them were discovered. It is wrong to contrast the sustainability concept with previous development approaches - when taking into account previously untreated problems, it is to some extent more like an elaboration of them.

When criticising the economy-centeredness of current development approaches it must be emphasised, that sustainable development is not in conflict with economic growth, but with its methods that are so damaging to nature, man and/or society. In 
the sustainable development strategy presented in the European Council in the 2001 meeting in Göteborg, it is noted that clear and stable objectives of sustainable development represent remarkable new potential for economy. This is potential, which by initiating a wave of technological innovations and investments creates economic growth and jobs. The European Council calls industries to participate in the development and use of new nature-friendly technologies in transport and energy fields. The European Council emphasises that to guarantee ecological sustainability it is important to distinguish economic growth and the additional use of resources (A European Union strategy ... 2002: 9).

Theorists, who have widened the sustainability concept from ecological problems to other fields, have often repeated the fault of the developers of the original "green" concept by contrasting one social life subsystem against another. Through a unilateral approach, the representative of each field tries to show that other fields discriminate and tackle the growth of the field developed by specific representatives. In the case of market failures, victims demand the intervention of the government, and in the case of such an intervention, the creation of a privileged position to their field. Historical experience proves that development strategies that emphasise one single field are not successful. In the development process different fields (nature, economy, culture etc.) do not collide, but instead the interests of their representants collide. As all fields are important for societal development, then developmental success can be achieved only by balancing the interests of their representatives, with the objective of achieving the internal strengthening of society and the improvement of the environment we live in. Sustainable development will not have original content from the denial of human-centredness (in the wider sense subjectcenteredness), but from consistent implementation.

The popularity of the term sustainability among influential people in society comes from the increasingly wider understanding that each subject must use universally and systematically in its approach to its future. That is why solutions must be found to institutional and methodological problems.

The main problem of the sustainability concept is that mankind's needs and interests towards some field (incl. natural environment) are considered in an abstract manner in the geographical, demographic and social sense. In the basic description by the Brundtland Commission, it is assumed that the existence of a generation forms a subject representing common interests. Still the interests of people and their associations are different and often contradictory. From the institutional viewpoint, sustainability means such a composition of society that the interests of all subject groups are adequately represented when planning development and making decisions. There must be an institution to represent the interests of each subject, which on the one hand considers them as their own and can perceive them in a complex manner, but on the other hand, can push them through with the same prestige as is done with the interests of other subjects. In this direction, the development sustainability concept grows along with institutional theory, the problems of which are not considered in the current paper. 


\subsection{Decision-making processes that guarantee development sustainability}

When viewing sustainable development in the broadest sense, it becomes necessary to analyse, plan and assess development in detail by considering all spheres of social life - demographic, cultural, psychological, social, political, economic and natural - as being equally important (as balanced). The complete approach demands that different fields must be viewed in a bilateral sense - that means systematically. The author supports the approach presented by Spangenberg (2001: 185), according to which sustainable development means the process of optimising an extremely complex functioning of the system. But the complex (versatile and systematic) demand of the development approach had already been in use for years before the development of the sustainability concept. Leading our attention to the fact that this demand was not fulfilled by current development approaches, a new development concept could not be developed, but by over emphasising the single areas they arrived back at the depleated/exhausted need to follow the principles of development approaches in the world as a whole and its parts.

From the methodological viewpoint, a scheme for decision preparation, receipt and implementation must be created, in which from all angles and systematically the need to guarantee development sustainability is taken into account. Many authors point to the connection between the sustainability concept and the decision-making process. The information that considers sustainable development must be prepared for use in the political decision-making process (Sustainability Indicators 1997: 6-7, 59-62; Moffatt et al. 2001: 196-198; Udo, Jansson 2009; Boggia, Cortina 2010; Uwasu, Yabar 2011).

At that point attention is focused on three approaches to the decision-making process - organisational (institutional), informational and analytical. From the organisational or institutional viewpoint, the starting point is the ideal maintained by the supporters of the green approach - "sustainability through democratisation" (Bell 2004: 94-95). In this respect, the UN Economic Commission for Europe approved the Aarhus Convention in $1998^{1}$. According to this convention, democracy must guarantee all people the right of access to environmental information and decision-making processes, and the right to turn to a court of law to guarantee that right. When expanding the sustainability concept from the environment to cover all society, people must be guaranteed access to information and the decision-making process in all public questions - cultural, social, regional and economic. That is why societal management institutions must be recast and gradually change from delivering a representative democracy towards a participative democracy (according to the growth in representative and cooperative potential of social groups).

\footnotetext{
${ }^{1}$ The United Nations Economic Commission for Europe (UNECE) Convention on Access to Information, Public Participation in Decision Making and Access to Justice in Environmental Matters was signed at the Fourth "Environment for Europe" Ministerial Conference in Aarhus, Denmark on 25. June 1998.
} 
According to the informational approach, this is dealt with via the development of an indicator system reflecting sustainable development, collecting initial information and creating a methodological base for processing that information (Sustainability Indicators 1997; Indicators of Sustainable ... 2001). In order to assess and forecast the sustainability of development in interested countries, there has been an attempt to involve national institutions to harmonise the necessary data collection and storage, initial processing of the data into indicators and procedures to transmit the data to interested institutions.

So far, from the sustainability perspective, there has been little attention paid to the analytical aspect of preparing decisions. Still, democratic institutions can only make decisions guaranteeing sustainability on the basis of access to adequate information on the condition that an analysis system satisfying that objective has been created. In light of the strengthening of democracy and the rising volumes of information, the weakness of the analysis system must be viewed as one factor that will bring sustainable approaches to a dead end (most important here is discrepancy between the objectives and the interests of different subjects). In order to make balanced decisions to guarantee sustainable development, certain requirements must be fulfilled when solving management problems, of which most important are the following:

* integrity - all elements and connections in the managing process must be considered as a complex whole, so it is possible to take into account and foresee all aspects of future developments (changes, effects);

* balance - to consider the development needs of all subsystems of human life (demographical, social, economical, cultural, political, psychological, ecological) as equally important in order to guarantee the equal quality and availability of all subsystems when fulfilling people's needs;

* perspective - when planning action, to foresee the direct and indirect long-term impact of that action on different subsystems of human life and changes taking place within them in order to avoid conflict between long-term and short-term development objectives;

* responsibility - to charge the subject (internalize) for all positive and negative results caused by it, so that every subject would try to maximise the positive and minimise the negative results of its action, no matter where or when the actions occur;

* ethics - to take into account and equally protect the interests of all subjects (individuals, social groups and clusters, nations of regions, different generations) connected to a process when planning and taking action, so that all subjects would be equally, sympathetically and responsibly treated; when communicating with the natural environment (nature, culture, social sphere, economy), the right to access resources from there is balanced with the responsibility to give back according to social cognition/feeling;

* economy - use natural and social resources in the best possible and least wasteful way;

* optimality - to choose best possible development option, taking into account all the above conditions in a balanced way. 
The conditions (standards, norms, border-values) set on different subsystems of social life provide information for structuring concrete management problems. Those conditions determine the limits of an optimisation problem, which every social subject seeking development options to maximize wellbeing has to take into account. From the perspective of sustainability, it is sensible to take into account the methodological basis of decision theory when locating the optimal development strategy. The methodological basis of decision theory tries to balance the following aspects when solving decision problems ${ }^{1}$ :

- the adjustment of local optimalities with global optimalities - this demands the division of the results of actions between subjects in such a way that instead of one activity being useful for one concrete subject (local), an alternative is chosen that is useful for society (globally) as a whole;

- subordinating short term activities to the best result in the long term - on the one hand, this requires the skill to measure long-term results and on the other, the use of mechanisms that avoid overestimating immediate benefit on the account of long term benefit;

- outlining manageable factors (room for alternatives) and non-manageable conditions (ambient conditions) - this requires the determination of the potential and responsibility of subjects when modelling the results of the action;

- taking into account objective criteria and subjective assessments - this requires the skill to assess viability and the how prone subjects are towards risks;

- solving problems with several optimality criteria - this requires solving the problem of finding a unified and quantified measurement for qualitatively different profitability estimations.

A separate problem is to determine indicators, with which it is possible to describe and assess development sustainability. The problem is not in the lack of indicators for monitoring and assessing sustainability, but choosing them from the abundance of indicators and taking into account bilateral connections. One internationally important challenge for all countries is to agree upon a unified set of indicators (Sustainability Indicators 1997, 7). Such an agreement is necessary to guarantee the international comparability of development sustainability.

The social, economic, ecological, cultural, political and psychological condition (development level) of society is described using different mass and volume indicators. On the other hand, as an indicator of the sustainability of a process the strength of the inner structure of that process can be used (vitality, rationality, economy, acceptance, probability of positive events etc.) in the form of relational and structural indicators. Any growth in the strength of the inner structure of a phenomenon is a mark of its development sustainability, even under conditions where the mass or volume values of the phenomenon are decreasing. A positive attitude towards life, solidarity and activity can keep a community with a small population sustainable. A different situation brings forth aspects that weaken the development of the phenomenon (with the growth in the mass or volume of the

1 Those questions have been considered by author in theoretic decision making studies: see (Рейльян 1989; Reiljan 2014). 
phenomenon, the internal structure becomes weaker). For instance, bringing together communities that do not cooperate well has resulting in a decrease in their sustainability due to conflict and disagreement.

The large number of indicators showing the mass (volume) and the strength or weakness of the inner structure of a phenomenon indicates the versatility of development sustainability. The analysis of sustainability means processing indicators that describe the target and the development, using the above given comprehensive and systematic principles. The problems connected with collecting and processing statistical data describe the sophisticated nature of analysing development sustainability.

\subsection{Sustainability in a competitive environment}

The rapid worldwide growth in openness (globalisation) raised the issue of development sustainability for many phenomena due to the growth in competition. That is why it is necessary to emphasise the need to consider competition when guaranteeing sustainability. The question is not whether some association could carry on existing in some isolated niche or under neutral external conditions, but it is necessary to assess the ability of the association to survive in an environment of free competition for existence.

From the viewpoint of competition (opposition of interests), sustainability is expressed as the position of the association in question in respect to other associations, whereas it is results focused, which in turn depends on some advantageous or disadvantageous characteristic or external influence. From the viewpoint of the assessment of the sustainability of an association it is rational to highlight both the narrow and broad approaches to competitiveness:

- according to narrow approach, competitiveness is viewed under the circumstances of a direct collision of interests between associations - the achievement of the objectives of one association does not allow the other to reach its objectives; from that, any growth in the sustainability of one association decreases the sustainability of the other;

- the broad approach also takes into account indirect and potential competition between associations - in fields where subjects have no direct contradictions and from which no direct influence effects the competitor's sustainability.

In the broad approach, the analysis of the competitiveness of the sustainability of the associations is the same as a comparative analysis in the broadest sense. The positive side of the broad approach is how it draws attention to the importance of comparison in the assessment of the characteristics of the association and the external environment - properties of association and the state of ambience can be meaningfully valued mainly in comparison with properties and the state of ambience of analogical associations. At the same time, adopting an approach that is too broad would make viewing the setting of concrete management tasks and analytical solutions to guarantee the sustainable development of the association too diffuse. 
The object of sustainability analysis in the narrow approach must be determined from the perspective of competitiveness as the contradiction between the interests of different associations, and as the search for ways to overcome these contradictions. Effective management concentrates on direct contradictions between associations that emerge with input and environmental conditions assuring existence, but also on realising their own interests with effective measures. When solving strategic management tasks, the analysis includes indirect and potential contradictions between interests appearing in the long run and also the strategic measures for overcoming them.

From the perspective of sustainability, the contradiction of interests between associations means that every association aims to be more successful in occupying their living space and guaranteeing ongoing existence. Therefore, sustainability means the potential for an association to exist along side other associations in spite of having contradictory interests. Such (co)existence can have several stages, which should be presented in order to estimate the sustainability of an association:

- the ability of an association to exist - the lowest level of sustainability, which indicates the ability to deal with the competitive environment and competitors' actions passively, without (remarkably) having to change or develop;

- the association's potential for development - medium level of sustainability, which indicates the ability to react actively to the nature of the competitive environment and changes in that environment, but also to competitors' actions, intensifying the activities of the association;

- the success of the association (advantage) - the highest level of sustainability, indicated in the ability to shape (influence) the competitive environment to create better characteristics via efficient actions and/or faster reactions.

The existence of an association that responds passively in a developing environment is only possible in a protected niche (basically the absence of competition, or some kind of exclusion), or where the association constantly abandons its positions (retreating to less attractive areas - basically avoiding competition). Such a position is unstable for the association and threatens it with the complete loss of sustainability when there is no more protection or possibilities for retreat.

Development capability means that the association makes persistent efforts to better its situation and shape the outside environment in order to ensure (better) sustainability. How much the actions of the association make the level of sustainability better or worse is dependent on the influence of factors shaping the environment and on the actions of other associations. In most cases, the sustainability of associations that are functioning actively should be better than of those counting on passive compliance.

Success (superiority) means the sustainability of the leaders in that field. Superiority means in one sense that the leader endangers the positions of other associations, threatening them with worse circumstances or extinction from competition, and in the other sense superiority means the leader shifts to become the competitor's focus of attention. Development oriented competitors use measures to catch the leader and 
take over its position. Being better demands innovation when at the same time competitors only need to copy in order to reduce the superiority of the leader. That is why superiority fixed at some moment is an important short-term feature of the safety of the association. In order to guarantee sustainability (long term assured existence) one must be constantly ahead of the competitors in development, and this demands superiority in implementing innovations and increasing the competitiveness.

From the perspective of competition, assessing sustainability is directly connected with defining the scope of the competition, according to which the following competition levels can be distinguished:

- local competition - the circle of competitors is limited to the nearest environment;

- regional competition - competitors in the association mainly originate from some limited region;

- global competition - competitors in the association can originate from anywhere in the world.

Growth in the scope of the competition often means more intense and stronger competition. Analysis of the scope of competition must be in accordance with the real scope of competition, so that all factors influencing the development of the association are covered, and that the analysis is not diluted by dealing with minor matters concerning the sustainability of the association.

To maintain an unsustainable association in the context of free competition, it is necessary to find an effective method for external intervention and optimal effect. When creating an external intervention system the objective should be to bring the development of the association to a level that allows it to manage in the context of free competition.

If there are similar associations, taking competition into account methodologically requires the use of a comparative analysis. Volume and level indicators make it possible to compare associations separated in space (for instance countries and regions) according to their achieved position and level. A subject at a higher development level can be rated as being more sustainable than those at a lower development level, when other circumstances are equal. The sources of information about sustainability are the development tendencies - certain changes in volume and level indicators. Positive tendencies would show the growth of sustainability or at least the potential for growth, when at the same time a sequence of negative changes would mean a decrease in sustainability or the potential for a decrease.

At the same time it must be taken into account that positive changes in the parameter values create only an environment for the sustainable development of the subject (association). The interaction of the association (for instance the society as a social whole) is not only dependent on the level of objective indicators in its inner structure, but people's subjective assessments of the phenomena and changes in them are also important. That is why from the subjective perspective sustainability is described using the portion of people satisfied with the circumstances of their 
existence and changes in them, and with the portion and influence of people in society with a positive attitude and future expectations. When increasing sustainability, the problem is not only achieving positive changes in an association's inner structure and in its relationships with the external environment, but also achieving changes in people with methods to generate positive attitudes.

\section{Basics of regional development sustainability analysis}

\subsection{The importance of regional development sustainability analysis}

In case of solving practical management problems general and abstract conception of sustainability must be transferred from global level to local and interests of different subjects must be taken into account. This means bringing out different levels in sustainability concept. General interest is mainly in global strategies and contracts (for instance Kyoto protocol), but also in the actions of powerful interstate unions (for instance EU). Still major work to guarantee development sustainability is done in independent countries, where hierarchical system must be developed, which would assess sustainability and would with the help of strategic management cover country as a whole and also its different level regions (Strategies for sustainable ... 2001: 29b-31).

The objective of current section is to adjust development sustainability concept on specific development task - balanced regional development - specific conditions solving. In order to achieve the objective the problems and importance of regional development balancing are viewed on different levels, after that the specifics of region are considered as object of sustainability analysis and at the end the structure of Estonian regional development sustainability analysis is created through dimensions, fields and indicators.

Taking into account development conditions of regions and specifics of interests of population has decisive role in regional development sustainability analysis. Development sustainability approaches considering world as a whole are contradictory with the need to consider objectives' differences between regions. For instance even in search of regulations guaranteeing the sustainability of natural environment it is not considered that opportunities and restrictions on human activities by nature, but also the dependence of human from nature, are remarkably different among regions. Sustainable development approach will have even larger problems when questions of demographic, cultural, social, economical and political development will be considered in their historical co-effect and spiritual (religious, psychological) context.

Implementing the communication and development models' rules of highly developed industrial countries in the whole world, means destruction of many other social associations with different content, because they will be not sustainable in the not natural competition circumstances. Abolishing economical, social and cultural development base will in turn initiate protest and resistance by people, which 
destabilises the development opportunities of the whole world. That is why beside authoritative globalisation ideology anti-globalisation criticism is also strengthening (Soborski 2004: 31-46).

So far good measures haven't been found to decrease unbalance in the regional development of the world. Since 1960ies the regional imbalance has deepened (see Soubbotina 2004). As the dictation over less developed countries is done in the shadow of "objective and scientific" sustainability concept, then such approach will raise doubts and criticism about the concept itself.

In EU the threats from regional unbalance to development sustainability are understood very well (political instability, migration, and urbanisation). European Commission raised the following regional aspect as one of the most important when giving guidelines to develop sustainable development strategy: "Regional unbalance in EU is still important concern" (A European Union strategy ... 2002: 21). The basics of politics directed to guaranteeing sustainable development were formulated by European Economic Commission in 2000 (ECE Strategy for ... 2001). EU common policies are mainly directed to regional development balancing. EU wish with common policies is to guarantee the harmonisation of development level and decrease backwardness in most unfavourable regions, including on islands and in rural areas. Still, imbalance in regional development of EU is growing (Reiljan 2010).

When guaranteeing regional development sustainability specific rural problems must be solved, about which good overview is given in the comparative analysis of eight Nordic and Baltic countries (see Nordic-Baltic Cooperation ... 2000). In that analysis the role of agriculture and forestry is emphasised as a method to guarantee jobs and income for rural population. In connection with preparing to join EU and being member of EU, European methods to guarantee rural life sustainability were gradually implemented in Estonia also. At the same time the influence of agriculture to rural life sustainability is twofold: intensive not nature-friendly agriculture from using chemicals in developed industrial countries will grow the employment in rural areas to some extent, but harms the supported and protected by government low intensity agricultural production of poor developing countries and leaves the lowwage rural population without income and work (Sustainable Development ... 2001: 33-34). To assess objectively the sustainability of agriculture and forestry, appropriate indicator systems have been developed (Sustainability Indicators 1997: 221-236).

Regional development sustainability is beside energy and communication supply highly dependent on the quality and presence of transport infrastructure. In the field of communication the availability of Internet for all regions and population groups is emphasised, in order to increase participation in and information about global processes (Sustainable Development ...2001: 25-26). 
The development of transport decreases distances and unites previously separate regions to larger unified regions. At the same time wider road network destroys natural environment and managing waste created by transport becomes more and more important environmental problem. The bearing role of transport in the development of economics and whole society and the increase in the load to natural environment makes finding a sustainable development path in that field very difficult and at the moment few progress has been made in that field (Sustainable Development ... 2001: 21). In order to consider sustainability problems connected with transport special indicator system has been developed (Sustainability Indicators 1997: 237-241). European Commission has given its guidelines in this respect (Europe at a crossroads ... 2003).

Energy supply is very uneven in different regions of the world. It means remarkable growth in energy consumption in the world in order to synchronise energy usage in different regions. An important problem in energy supply is the large proportion of depleting fossil fuels, which in turn troubles natural environment with large and constantly growing amount of waste (Sustainable Development ... 2001: 40-43). Two billion people live without electricity in the whole world and that is why supplying electricity has decisive role in order to achieve the objective in Millennium Declaration: to decrease the number of people living in poverty by half by the year 2015 (Energy and sustainable ... 2002: V).

In Estonia serious work must be done to develop European-like regional policy. According to the assessment of European Commission, Estonia is distinguished from other same size EU regions by several common features: Estonia lies geographically away from European core regions, having relatively modest transport connections. Estonia is sparsely populated compared to other European regions (ca 75\% less people per square $\mathrm{km}$ than EU average) and also an EU member state where population and labour force is decreasing the quickest. In Estonia regional development differs remarkably from those of other same size EU regions (Eesti regionaalarengu ... 2004, point 3.1) Economic imbalance of Estonian regional development is growing (reiljan 2012).

In conclusion transition of development sustainability from global to regional means the substitution of problems of mankind as a whole against living environment and vital activity problems of different territorial units. Solving the development problems of the whole and its parts needs complex approach, which includes:

a) opening local development impulses - bringing out local uniqueness and developing it to attract attention of investors, workers and new residents;

b) seeking local development possibilities - opening the resource and market potential of different economic fields;

c) developing local infrastructure - guaranteeing vital activities with transport, communication, electricity and water supply infrastructures;

d) taking into account the role of competition on local development - the regional positioning and migration of people from different life, work and production conditions; 
e) the role and possibilities of over-region institutions at supporting the uniqueness of regions and balancing regional development.

\subsection{Region as object of sustainability analysis}

Region is a specific object from the development analysis viewpoint, which demands using sustainability conception with its peculiarities. Mainly the problems rise from using global conceptions locally, that means on parts of the whole. Sustainability was considered globally in the beginning - for instance attention was paid on world's natural environment ability to supply whole mankind with resources, but also on absorbing and neutralising the consequences of human activities. Assuming that the influence of outside environment (for instance solar energy arrival on earth) does not change, world could be considered as closed system, in which all changes affect one and only subject - mankind. The action of single subject in closed space is an assumption, which remarkably makes the methodological base of sustainability analysis easier. Firstly, in case of global approach there are no problems common to local approach, which mainly are connected with the different interests of subjects and internalising the results of their activities. Secondly, in case of global approach the subject "plays" with nature and with neutral partner from the aspect of interests and risk (using terminology of game theory), when at the same time one must take into account reaction (support, indifference, counteraction) to development strategy because of diverse objectives and action possibilities of different subjects (social groups, population of different regions and other interest groups) when considering the local approach. Thirdly global approach pays attention to competition between species in associations when exploiting resources, but there will be no problem of competition between subjects from the same species, as it is common to local approach.

As sustainable development approach assumed (by default) one subject and closed space, it was reproached for planned economy and interventions, because without those instruments there is not possible to consider fragmented world as a whole. In such case there are tasks for all levels starting from international organisations and ending with municipalities. (The politics of sustainable ... 1997: 19-20)

From the above given it can be concluded that when moving from global to local (branch of economy, region, social cluster) level in sustainability approach, development management problems become more concrete and complex. But at the same time the specifics of development sustainability concept becomes more dull when localising management systems and common principles, conceptions and theories raise more and more in problem formulation:

- competitiveness concept in economics,

- justice principle in social sphere,

- need of balance in regional development,

- saving approach when exploiting natural environment,

- need of democracy in politics. 
The specifics of sustainability conception in local context is bounded more and more with the need to follow methodological principles given in previous secsen when formulating development problems and preparing and accepting development decisions. The objective is to guarantee the internal unity of different fields and best result of their co-effect.

Region in socio-economic sense is a territorial unit, which has more intense relationships (cooperation, influence, information exchange) between subjects belonging into it compared to relationships with subjects outside that region. That is why the term region is quite wide. The most typical regional unit is a country. Common legislation and administration, in most cases linguistic and cultural solidarity and religious background support interstate cooperation of people and firms, when at the same time communication with subjects in other countries is in addition to differences in before mentioned substantial aspects problematic because of obstacles (restrictions, special permits, taxes and control mechanisms connected to them) set by government in cross-border communication. That is why indicators and methods of county's development sustainability can also be used in regional development sustainability analysis. Unfortunately country's development sustainability analysis does not have a common theoretical and methodological base so far.

The term region is still mainly used to mark territorial units other than country. That is why the ties between regions and development of some country can be viewed from the following aspects:

- the independence of the development of country from meta-region, into which it geographically belongs;

- the influence of country over meta-region development, into which it geographically belongs;

- the dependence of the development of country from micro-regions of which the country consists of;

- the influence of country over micro-regions of which the country consists of.

In global economics an important role is on historical co-effect areas, which cover several countries and their parts (Mediterranean region, Caribbean Sea region, Baltic Sea region etc.). The sustainability of such regions is dependent on the rationality, will and capability of cooperation. Secondly, situation and cooperation perspectives in region influence the development of countries in that region. Surely the resultfulness of the development of Estonia is dependent on the development of countries in Baltic Sea region and cooperation between them, but at the same time Estonia also gives its contribution to Baltic Sea region development. From 1st of May 2004 Estonia belongs to one of the largest regional union of countries European Union - and the countries in it must follow voluminous common legislation and regulations in communication with countries outside EU. That important regional development aspect - the relationship between country development and meta-region - will not be included in current approach. 
Most important structural elements of country are its territorial parts (micro)regions. The regional structure of country is hierarchical. Administratively specified interaction areas in Estonia are 241 municipalities (parishes and towns, from October 2005227 units) on first level, 15 counties on second level and 4 regions in highest level. In addition to administrative determinant, regions can be distinguished according to other features stimulating cooperation between different subjects (for instance language, culture, religion, but also transportation network). On the cultural basis there is strong cooperation in Estonia for instance between historical Setomaa regions. Good transportation possibilities favour interaction as work force area of pull-centre - (town-like)settlement - and its background areas ${ }^{1}$. In current work the base of distinguishing regional units is administrative feature, because:

a) public sector large share results in high importance of administrative institutions and responsibility for organising and influencing the work of different subjects,

b) administration is with common nature and influence in the whole territory of country,

c) administratively regions are uniquely defined and clearly distinguishable,

d) information about regions is collected and processed through administrative units.

Municipality units, counties and regions have different ability to perform as regional units.

- As clearly different regional subject only municipality can be brought out, where there is executive body assigned by municipal council, which is elected by people inhabiting that municipality, and which acts in the frames of its budget and directs the territorial development. Municipalities were mainly restored in the pre-Soviet occupation boundaries and their centres are local life pull-centres formed in historical development. The ability of municipality to perform as regional development unit is highly dependent on that how much the municipality centre can act as pull-centre in modern conditions. That function can at the moment be fulfilled mainly by town-like establishments; centres of rural municipalities are limited to arranging life in the background of pull-centre.

- Counties do not have their own budget or management institutions, because county heads mainly fulfil central government's representation and control functions. The development of county as a whole is to some extent directed by analysis and coordination activities of county governments and municipalities, but they do not have sufficient resources to have remarkable effect. As administrative units counties lose their positions as many central government institutions have been transferred from county centres to region centres. County position as regional development unit is strengthened to some extent by the fact that they are commonly the most important economical and cultural pull-centres of county, but its retroaction

\footnotetext{
${ }^{1}$ In Estonia up to 44 pull-centres can be distinguished, which can create work-force area around them (Eesti regionaalarengu ... 2004, point 3.3). Pull-centers are difficult to be used as regional analysis centres, because they do not always coincide with borders of administrative units and that is why no systematic information is collected about them.
} 
to municipality's development is modest (it is mainly limited to collecting taxes received from the income of commuting people).

- Regions differ in Estonia only because in their centres there are some important central government institutions serving the whole region (for instance police, registers). But there is not administrative subject influencing the development of region in the socio-economic sense. The biggest Estonian towns as centres of the region are important socio-economical pull-centres, but their back-influence to the development of county is irrelevant. So regions can be brought out mainly from the statistical viewpoint.

Derived from the above regional development problems in Estonia must mostly be considered in the level of municipalities, where certain institutions deal with development planning and analysis. In the level of counties and regions it is in absolute measures and in comparison with other regions and counties mainly statistically possible to bring out the region's private subjects' initiative from one side and central government's and municipalities' collected results of decision making from the other side.

The regional problems of country development sustainability must that is why be considered from the three following aspects:

- $\quad$ sustainability of development of micro-regions;

- central government's influence on the sustainability of the development of micro-regions;

- micro-region's influence on country's development sustainability.

Counry and its territorial parts are quite similar from the methodological aspect of development sustainability, except the greater effect of random events, possibilities to obtain information and reliability on assessing the development tendencies. The smaller the territorial unit, the smaller are the observations that are base for statistical estimations. Estimations made or trends brought out on the base of small samples are less precise and not so reliable, because they can be influenced by random factors. That is why interpretation of results of statistical analysis of small regions must be done extremely carefully.

\subsection{Structure of regional development sustainability analysis}

Development of regions is as much many fold as the development of countries, but many aspects cannot be measured and managed on regional level due to information lack, fragmentariness or randomness. Followingly there has been presented sustainability analysis structure of region by dimensions and different aspects of dimensions, considering Estonian municipalities and counties as regions. The following structure of country's regional development sustainability analysis can be concluded when taking into account the principles given in the first section of current article. 


\section{A. Measuring development sustainability of regions in different fields:}
a) population,
b) living quality,
c) labour market,
d) entrepreneurship,
e) natural environment.

In order to get an overview of development sustainability of a region universal dimensions (social, economical, ecological) are used in the literature of this field. The international presentation of Estonian sustainability is also based on the threedimensional distribution of social life (Estonian National ... 2002). To emphasise the human-centeredness of sustainability concept, social dimension is considered in three sections. At first population is analysed, which presents a start point and a final destination when planning the development of region. In region mainly people living there are active and changes are mainly made to improve their living standard. That is why after population analysis living quality is considered, which from one side characterises historically achieved development level, but from the other side base for future development. Labour market unites living quality of man with material economic activity assuring it (entrepreneurship) - viewed from that aspect man acts as labour. As a result of entrepreneurship analysis we can value economical initiative, organising and performance ability of population of a region and also business environment. Natural environment supplies economic activities with resources and population with living environment, at the same time absorbing and neutralising traces of human activities. That is why environment has a remarkable role when assessing sustainability of development.

\section{B. Government's influence on the sustainability of the regional development:}

a) administrative capability of regions,

b) supply of local public services in region,

c) development level of infrastructure in region,

d) regional development programs of the government,

e) government programs and local measures to develop entrepreneurship,

f) aid of central government to municipalities.

To favour regional development it is necessary to find optimal division of administrative services between central government departments and regional governments. After that the central question is the assurance of administrative capabilities of regional institutions, which mainly means proper funding of the tasks given to them and educating necessary task specific staff.

Sustainability of regional development depends on the presence and quality of infrastructure. The development of road network connecting regions is highly dependant on central government' financing, because financial base of local governments is not sufficient to fund such big investments. In addition to that 
central government separately donates public transport - buses, trains, but also ferry transport between mainland and islands. Central government also donates postal service preservation in rural areas, with what equality of postal service prices among regions is guaranteed.

Regional development programs of the central government are meant to support population of some special regions (for instance Estonian small islands) or preserving regions with specific features (for instance Setumaa). To assure the sustainability of environment government does important work with supplying population with fresh water, liquidating sources of nature pollution, but also preserving ecological rarities in landscape protection areas and introducing them to public (creating nature paths and houses). In EU special program is implemented for developing cooperation in border areas.

Government has also important role in guaranteeing the sustainability of entrepreneurship in regions. Regional entrepreneurship supports grew several-fold in Estonia after joining EU, although some programs (for instance SAPARD) were implemented already before. Regional entrepreneurship support is needed to compensate cost differences from different lengths of transport roads and other factors. Agricultural support must compensate costs in that economic branch, which emerge in connection with nature preservation, landscape care and rural settlement assurance. Local governments must guarantee smooth carriage of affairs of problems in their responsibility, because in many cases they do not have resources to support firm tangibly. Larger municipalities pay support to start-up business. In special conditions (for instance on small islands) municipalities are financed according to special system by central government in order to guarantee sustainability, because financial basis forming according to overall funding scheme would not allow them to fulfil given tasks. In summary it can be concluded that public administration's, public sector investments', supports' and services' role is remarkable and does not show decrease tendency in Estonia in the following years.

\section{Influence of regions development level on the development of country:}

- balance of coubtry's regional development,

- development of economical cooperation clusters.

The development of country is as sustainable as balanced is its regional development. Unexplained high differences between the living standard and social conditions of population in different regions cause dissatisfaction among people and political tension. Social coherence and political stability is an important presumption of country's development success. Large development differences cause interstate migration and commuting, which decreases living standard, deepens development problems of donation regions, but also causes problems in growth centres.

An important factor of country economic development's sustainability is cooperation between firms in value creation process. The presumption of it is even 
development of firms in different branches of economy. In Estonia extremely important is the usage of abundant land and forest resources in the name of country's development. That is why equal development of rural areas with industry and service concentration areas must be guaranteed (pull- and growth-centres), so that full economic cooperation clusters could be formed.

\section{Summary}

At the beginning of the current article, the generic abstract approach to sustainability is presented, which is suitable for describing the development of all subjects and associations. Sustainability (sustainable development) indicates positive properties or environmental situations (their changes) from the viewpoint of some subject or association, which guarantee the long-term existence (strengthening) of the subject or association. Assessments of sustainability come from the subject's values, and this forms the basis for its attempts at making its situation better. Such an approach was followed in subsequent analyses of the nature of sustainability using concrete sustainability definitions (given in literature).

In the second subsection is analysed the contradictions derived from the unilateral approach to sustainability. The current approaches to sustainability mainly show the concern of their supporters for (mis)developments in the natural environment and society and an abstract desire to eliminate negative phenomena. The fact that different subjects see problems or possible solutions differently on the basis of their own interest is not taken into account. Radical approaches to sustainability lead attention away from the real source of the sustainability problem by using idealistic and emotional assessments and by offering solutions that do not take into account the power lines between the social groups concerned - the dominance of economic interests in all social decisions. To solve the sustainability problems, the economycentred development approach must be replaced by a development approach that is focused on improving people's quality of life.

In the third subsection is showed that guaranteeing sustainability can be considered a decision-making process with specific properties and restrictions, which must guarantee the complex consideration all aspects of the functioning of society. Sustainability cannot be guaranteed by (over)emphasising one aspect and all aspects must be considered equally when making development decisions. As the organisational (institutional) and informational aspects of the social decision-making process directed at guaranteeing sustainability have been thoroughly discussed in the literature, then the main focus is currently set on the analytical side.

In the next subsection is considered the need to take into account competition when planning sustainable development. Due to competition such associations become sustainable, which often make efforts to gain success over competitive associations by making their own characteristics better or turning external environmental conditions in their own favour. At the same time people's subjective attitude is important beside the conditions of competition when guaranteeing sustainability. 
In the second section previously developed principles of sustainable development conception were used to view regional development. In the first subsection the importance to guarantee regional development sustainability and its problems in the whole world, EU and Estonia were considered. The complex nature of the field is proven by the fact that no matter the perceival of its importance, no real solutions have been found - regional nonsustainability deepens consistently. Institutions founded to solve regional development problems and development plans made cannot fulfil hopes connected with them. In Estonia problems mainly connected with guaranteeing rural life sustainability have not been solved.

In the second subsection is considered sustainability of region as analysis object. Transition from global approach to local needs taking into account discrepancies between subjects and considering competition as an important factor of interregional relationships. Through that analysis becomes more concrete, but then the sustainability conception transforms in certain fields to long known approach of concepts (competitiveness in economics, justice in social sphere, sparing when using natural resources etc.). Sustainability reveals more not as a property of viewed object, but as a methodological principle of balanced decision preparation, making and executing guaranteeing. Derived from the Estonian regional structure analysis the base of determining region are clear administrative limits when executing power and directing development in territorial unit, the main regional unit is municipality (town or parish) in this approach.

In the third subsection is considered the structure of regional development sustainability analysis. At first regional development was viewed from the aspect of five fields (population, living standard, labour market, entrepreneurship and natural environment). Then the influence of government on regional development sustainability as administrative capability and public sector services provider was viewed. At last regional development influence on country as a whole was considered.

\section{References}

1. Afgan, N. H. (2011) Sustainability Concept for Energy, Water and Environment Systems. - in: Gökçekus et al. (eds.) Survival and Sustainability, Environmental Earth Sciences, 447 DOI 10.1007/978-3-540-95991-5_41, -Berlin, Heidelberg: Springer-Verlag. - pp 447 - 469.

2. Barraclough, S. L. (2001) Toward integrated and sustainable development? Geneva: United Nations Research Institute for Social Development.

3. Barry, J., Baxter, B. (2004) Editors' introduction. In Europe, globalization and sustainable development. Barry, J., Baxter, B., Dumphy, R., eds. London, New York: Routledge, 1-12. 
4. Bartelmus, P. (2000) Sustainable development: paradigm or paranoia? International Journal of Sustainable Development, 3, 4, 358-369.

5. Becker, E.; Jahn, T.; Stiess, I.; Wehling, P. (1997) Sustainability: A CrossDisciplinary Concept for Social Transformations. MOST Policy Papers, 6.

6. Bell, D.R. (2004) Sustainability through demokratization? The Aarhus Convention and the future of environmental decision making in Europe. In Europe, globalization and sustainable development. Barry, J., Baxter, B., Dumphy, R., eds. London, New York: Routledge, 94-112.

7. Boggia, A; Cortina, C. (2010). Measuring sustainable development using a multi-criteria model: A case study. - Journal of Environmental Management, 91. - pp 2301-2306.

8. Christen, M, Schmidt, S. (2012) A Formal Framework for Conceptions of Sustainability - a Theoretical Contribution to the Discourse in Sustainable Development. - Sustainable Development, 20, pp 400-411.

9. Deep Ecology for the Twenty-First Century Readings on the Philosophy and Practice of the New Environmentalism. (1995) Sessions, G., ed Boston and London: Shambhala Publications Inc. .

10. Dempsey, N.; Bramley, G; Power, S.; Brown, C. (2011) The Social Dimension of Sustainable Development: Defining Urban Social Sustainability. - Sustainable Development, 2011, 19. - pp 289-300.

11. Economic Comission for Europe (2001) ECE Strategy for a Sustainable Quality of Life in Human Settlements in the 21st Century. New York and Geneva: United Nations Publications.

12. Eesti regionaalarengu strateegia 2004-2015. a. Eelnõu.(2004) Eesti Vabariigi Siseministeeriumi regionaalarengu osakond.

13. Energy and Sustainable Development. Case Studies. New York: United Nations, 2002.

14. Estonian National Report on Sustainable Development 2002 (2002) Tallinn: Estonian Comission on Sustainable Development.

15. Europe at a crossroads. The need for a sustainable transport. Luxembourg: Office for Official Publications of the European Communities, 2003.

16. European Comission (2002) A European Union Strategy for Sustain able Development. Luxembourg: Office for Official Publications of the European Communities.

17. Indicators of Sustainable Development: Guidelines and Methodologies. (2001) United Nations, Department of Economic and Social Affairs, Division for Sustainable Development, http://www.un.org/esa/sustdev/natlinfo/indicators/indisd/indisd-mg2001.pdf

18. McKinley, T. (1997) Linking Sustainability to Human Deprivation. In Sustainability indicators: A Report on the Project on Indicators of Sustainable Development. Moldan, B., Billharz, S., Matravers, R., eds. John Wiley \& Sons: Chichester, New York, Weinheim, , Brisbane, Toronto, Singapore, Box 30, 253-255.

19. Moffat, I., Hanley, N., Wilson, M. D. (2001) Measuring and Modelling Sustainable development. New York and London: Parthenon Publishing Group. 
20. NGLS Handbook of UN Agencies, Programmes, Funds and Conventions Working for for Sustainable Economic and Social Development. Third Edition. New York: UN NGLS, 2000.

21. Nordic-Baltic Cooperation on Sustainable Rural Development. Country Note Report. - TemaNord, 2000.

22. Nõmmann, T., Luiker, L., Eliste, P. (2002) Eesti arengu alternatiivne hindamine - jätkusuutlikkuse näitajad. Tallinn: Poliitikauuringute Keskus PRAXIS.

23. Oja, A. (2001) Millised on eesti eeldused olla jätkusuutlik väikeriik? Riigikogu Toimetised, 3, 236-248.

24. On the Way to Sustainable Development: an approach to defining a national model of global responsibility (1997) (2nd ed). The Finnish Society of Future Studies and FICOR.

25. Pelstring, L. Measuring Environmental attitudes. The New Environmental Paradigm. Viidatud Tafel 2003, 150 kaudu.

26. Pezzey, J. C. V., Toman, M. A. (2002) The Economics of Sustainability: A Review of Journal Articles. Resources for the Future Discussion Paper, 02-03.

27. Pravdic, V. (2002) Sustainability and Sustainable development: the Use in Policies and the Ongoing Debate on These Terms. Croatian International Relations Review, VII, 93-99.

28. Reiljan, J. (2014) Majandusotsuste analüütiline põhistamine. Tartu: TÜ Kirjastus. $414 \mathrm{lk}$

29. Reiljan, J. (2010) Possibilities of Discussing Convergence of Regional Economic

30. Development in the EU. -- Proceedings of the Institute for European Studies. -Tallinn University of Technology, No. 8, pp $33-60$

31. Rahnama, M.R.; Yazdanfar, H (2014) A sustainable urban development and crises management: Empirical investigation on redesigning Tehran Arg square. Management Science letters 4, pp 2003-206.

32. Reiljan, J. (2012) Vergrösserung der regionalen disparitäten der Wirtschaftsentwicklung Estlands. -- Die Soziale Marktwirtschaft als Vorbild in internationalen Krisen. Ökonomischer und technologischer Wandel zwischen 1989 und 2009. Ordnungspolitische Dialoge. Bd. 3. Seliger, Bernhard / Sepp, Jüri / Wrobel, Ralph (Hrsg.). -- Frankfurt am Main, Berlin, Bern, Bruxelles, New York, Oxford, Wien, S. 121-145

33. Soborski, Rafal (2004) Anti-globalism and ecologism in comparative perspektive. In Europe, globalization and sustainable development. Barry, J., Baxter, B., Dumphy, R., eds. London, New York: Routledge, 2004, 31-46.

34. Soubbotina, T. P. (2004) Beyond Economic Growth: An Inroduction to Sustainable development (2nd ed). Washington, D.C.: The World Bank.

35. Spangenberg, J. H. (2001) Investing in sustainable development: the reproduction of the mammade, human, natural and social capital. International Journal of Sustainable Development, 4, 2, 184-210.

36. Strategies for sustainable development / OECD Development Assistance Committee (DAC). Paris : Organisation for Economic Co-Operation and Development, 2001. 
37. Sustainability Indicators: A Report on the Project on Indicators of Sustainable Development (1997) Moldan, B., Bilharz, S., Matravers, R. eds. Chichester: John Wiley and Sons, 1997.

38. Sustainable Development and the New Economy. Forum Highlights. In OECD Forum 2001, July 2001.

39. Tafel, K., Terk, E. (2003) Jätkusuutlik areng. Teoreetilised ja praktilised dilemmad. Strateegia Säästev Eesti 21 taustmaterjal 1, http://www.seit.ee/projects/147-196.pdf

40. Taylor, J. (2002) Sustainable Development. A Dubious Solution in Search of a Problem. Policy Analysis , 449. The Cato Institute's Web Page 12.10.2005. http//:www.cato.org/pubs/pas/pa449.pdf

41. The politics of sustainable development. Theory, policy and practice within the European Union (1997) Baker, S.,, Kousis, M.,, Richardson, D., Young, S. eds. London-New York: Routledge.

42. The World Comission on Environment and Development (1987) Our Common Future. Oxford-Nev York: Oxford University Press.

43. Tüür, Kadri (2000) Looduse vastu ei saa. Kogumikus Tekst ja loodus. Tartu: Eesti Kirjanduse selts, 11-18.

44. Udo, V. E; Jansson, P.M. (2009) Bridging the gaps for global sustainable development: A quantitative analysis. - Journal of Environmental Management, 90.-pp 3700-3707.

45. Uwasu, M.; Yabar, (2011) Assessment of sustainable development based on the capital approach. - Ecological Indicators, 11. - pp 1348-1352.

46. Williams, C. C.; Millington, A. C. (2004) The diverse and contested meanings of sustainable development. The Geographical Journal, 170, 2, 99-104.

47. Wiman, R. (1999) Putting People at the Centre of Sustainable Development. Proceedings of the Expert Meeting on the Social Dimension in Sustainable development. Volume I: Policy themes and synthesis. Saarijärvi: Gummerus Printing.

48. Рейльян Я. (1989) Аналитическая основа принятия управленческих решений. - М: Финансы и статистика. 206 с. 


\title{
REGIONAALARENGU JÄTKUSUUTLIKKUSE ANALUUSI KONTSEPTSIOON
}

\author{
Janno Reiljan ${ }^{1}$ \\ Tartu Ülikool
}

Jätkusuutlikkuse mõiste on arenguga seoses leidnud aktiivset kasutamist kavandatava tegevuse ihaldatava perspektiivse eesmärgi - looduse või ühiskonna seisundi - ühe tähtsama iseloomustajana. Jätkusuutlikkus tähistab olukorda, milles soovitud nähtusele on tagatud sisemine tugevnemine ja positsioonide paranemine konkurentide suhtes (jätkusuutlik areng) või vähemalt pikemaajaline kestmine (stabiilsus). Jätkusuutlikkuses väljendub soov tasakaalustada kindlustunnet sisendav püsimine (stabiilsus) ja uue poole pürgiv muutumine (areng). Selles mõistes väljendub usk tuleviku suhtes, kus arengu käigus loodetakse nähtuse mittesoovitavate omaduste kadumist ja soovitavate iseloomujoonte tugevnemist või säilimist.

Jätkusuutlikkusele kui üldistatult ja avaralt käsitletavale märksõnale omistatakse erinevates valdkondades erinev konkreetne sisu. Välja on töötatud sadu jätkusuutlikkuse määratlusi. Erinevad vaated arengule tulenevad erinevate subjektide lähteolukorra ja käsutatavate vahendite erinevusest, aga samuti subjektiivsete väärtushinnangute lahknevusest. Objektiivsetest põhjustest tulenevast ideede paljususest tuleb igas valdkonnas välja töötada oma spetsiifiline lähenemine arengu jätkusuutlikkuse analüüsile.

Käesoleva artikli eesmärgiks on välja töötada regionaalarengu jätkusuutlikkuse analüüsi kontseptsioon. Eesmärgist lähtuvalt on ülesandeks seatud käsitleda jätkusuutlikkuse kvalitatiivse määratlemisega seotud probleeme, kontseptsiooni ühendamise võimalusi arengu hindamise metodoloogiliste alustega ning jätkusuutlikkust hindava subjekti olemusega. Kõigepealt piiritletakse jätkusuutlikkuse mõiste ja seejärel analüüsitakse jätkusuutlikkuse olemust. Kolmandas alapunktis tuuakse välja arengu jätkusuutlikkust tagavale otsustusprotsessile esitatavad nõuded ja neljandaks käsitletakse jätkusuutlikkust konkurentsitingimustes.

Jätkusuutlikkuse mõiste kerkis esile seoses ühiskonna (eelkõige majanduse) ekstensiivsest arengust ja pillavast tarbimisest tulenevate ökoloogiliste probleemide teravnemisega. Looduskeskkond ei suuda enam taluda inimtegevuse tulemusena tekkinud koormust. Eelkõige tuuakse välja ressursside üleekspluateerimine ja raiskamine, elukeskkonna halvenemine seoses looduse absorbeerimisvõimet ületava saasteainete emissiooniga, inimtegevusest tulenevad kliimamuutused ning loodusliku mitmekesisuse vähenemine taime- ja loomaliikide hävimise tõttu. Jätkusuutlikkuse mõistega tähistati algul seetõttu sisuliselt ökoloogiliste koosluste

\footnotetext{
${ }^{1}$ Prof. Dr. Janno Reiljan, University of Tartu, EST-50090 Tartu. janno.reiljan@ut.ee
} 
võimalikult pikaajalist kestmist, nende säilitamist järgmistele põlvkondadele teadliku organiseeritud sihipärase ennetus- ja kaitsetegevuse abil.

Analoogselt ökoloogilistele kooslustele nõrgenevad ja kaovad leviala avatuse suurenemise (näiteks globaliseerumise) tingimustes inimtegevuse tagajärjel ka paljud varem suhtelises isolatsioonis arenenud sotsiaalsed, kultuurilised, politilised ja majanduslikud kooslused. Positiivseks tunnistatud muutuste kõrval ilmnevad ühiskonna arengus ka nähtused ja tendentsid, mida käsitletakse ühiskonda kahjustavatena. Inimkond ei käi hoolimatult ümber mitte ainult loodusega, vaid ka enda poolt loodud sotsiaalsete, kultuuriliste ja muude väärtustega. Ka kultuuris, sotsiaalsfääris, poliitikas ja majanduses ilmneb üha teravamalt inimese ja tema elukeskkonna suhete ümberhindamise vajadus. Seetõttu võeti jätkusuutlikkuse mõiste suhteliselt kiiresti kasutusele väga erinevate valdkondade arengukäsitlustes.

Jätkusuutlikkuse mõiste kasutuselevõtul on mõte ainult seoses inimeste teadliku normatiivse tegevusega mingi koosluse arengu kavandamisel ja suunamisel. Inimene mitte ainult ei kohane keskkonnaga, vaid üritab eksistentsi kindlustamiseks ja tugevdamiseks oma teadliku sihipärase tegevusega ennast ja keskkonda muuta. Arengu jätkusuutlikkuse (mittejätkusuutlikkuse) tunnetamine tähendab sisuliselt nendele muutustele mingi subjekti seisukohalt väärtushinnangu andmist. Väärtushinnangud muudavad jätkusuutlikkuse mõiste subjektiivseks.

Arenguga seostatult muutub jätkusuutlikkuse mõiste suhteliseks. Koosluse kvaliteedi (olemuse) püsimise ja uueks kvaliteediks ülemineku (arengu) piirid on ähmased. Jätkusuutlikkus (jätkusuutlik areng) tähistab mingi koosluse tuleviku seisukohalt positiivseid muutusi, mis tagavad vaatlusaluse koosluse pikaajalise püsimajäämise (tugevnemise).

Jätkusuutlikkuse käsitlused väljendavad senini eelkõige nende esindajate muret looduskeskkonnas või ühiskonnas toimuvate (väär)arengute pärast ja head tahet arvatavalt negatiivsed muutused edaspidi ära hoida. Paraku näevad erinevad subjektid nii probleeme kui ka võimalikke arenguvariante oma huvidest või väärtushinnangutest tulenevalt erinevatena. Seetõttu on mõistetav, miks omistatakse jätkusuutlikkuse mõistele kasutusvaldkonnast ja üldistusastmest olenevalt, aga ka käsitleva subjekti lähenemisviisist tulenevalt väga erinevaid tähendusi. Mingit ühte õiget või ühtset ja terviklikku jätkusuutlikkuse hinnangut ei saagi subjektide huvide ja väärtushinnangute lahknevuse tõttu tekkida. Küll aga on mõttekas töötada arengu jätkusuutlikkuse analüüsi ja hindamise metodoloogiliste aluste täiustamise ja ühtlustamise eesmärgil.

Probleemiks ei ole nn antropotsentristliku maailmavaate valitsemine ja arengu jätkusuutlikkuse tagamisel ei seisa vastamisi inimene ja loodus. Probleemiks on majandus(huvid)e despootlik võim kõigi teiste ühiskonna allsüsteemide ja looduskeskkonna üle. Ometi on ju majandustegevuse ainsaks õigustuseks inimese (arengu)vajaduste teenindamine, mis võib muuhulgas eeldada ka loodusressursside (säästlikku) kasutamist ja inimese käsitlemist majandusprotsesside osana (tööjõuna). 
Arengu jätkusuutlikkuse tagamisel on vaja seniselt majanduskeskselt arengustrateegialt üle minna inimkesksele, allutades majandustegevuse inimarengu (hõlmab nii üksiku indiviidi kui ka ühiskondlike suhete arengu) jätkusuutlikkuse tagamise vajadustele. Kahtlemata tekitab arengu jätkusuutlikkuse majanduskeskse käsitluse ületähtsustamine probleeme. Aga reaalselt rakendatavaid lahendusi ei paku ka ühekülgselt mingit teist valdkonda ületähtsustavad käsitlused.

Arengu jätkusuutlikkuse ökotsentristliku käsitluse põhivastuolu tuleneb maailma eri piirkondade, riikide ja nende osade arengutasemete ebavõrdsusest. Käesoleva töö autor toetab seisukohta, mille kohaselt ei saa majanduskasvu loodusressursside kasutamisest lahtisidumisest ühte moodi rääkida kõige vaesemate rahvaste (elektrikulu ühe elaniku kohta $80 \mathrm{kWh}$ aastas) ja kõige rikkamate rahvaste (elektrikulu inimese kohta $8000 \mathrm{kWh}$ aastas) arenguprobleeme käsitledes. Jätkusuutlikkuse kontseptsiooni põhiprobleem seisneb selles, et inimkonna huvisid ja vajadusi mingi valdkonna (sh ka looduskeskkonna) suhtes käsitletakse abstraktselt ühetaolistena nii geograafilises, demograafilises kui ka sotsiaalses lõikes.

Arengu jätkusuutlikkuse kontseptsioon taandub dimensioonide aspektist vaadelduna vajadusele analüüsida, kavandada ja hinnata arengut igakülgselt, käsitledes võrdväärselt tähtsana (tasakaalustatult) ühiskonnaelu kõiki valdkondi: demograafilist, kultuurilist, psühholoogilist, sotsiaalset, poliitilist, majanduslikku ja looduslikku. Terviklik käsitlus nõuab, et erinevaid valdkondi vaadeldakse vastastikuses toimes, st süsteemselt. Jätkusuutlik areng kujutab endast äärmiselt kompleksse süsteemi funktsioneerimise optimeerimise protsessi. Arengukäsitluse komplekssuse (igakülgsuse ja süsteemsuse) nõue oli aga kasutusel aastakümneid enne jätkusuutlikkuse kontseptsiooni teket. Metodoloogilisest aspektist tuleb luua otsuste ettevalmistamise, vastuvõtmise ja täideviimise skeem, milles igakülgselt ja süsteemselt arvestatakse arengu jätkusuutlikkuse tagamise vajadust.

- Arengu jätkusuutlikkust kindlustavate tasakaalustatud otsustuste vastuvõtmiseks tuleb juhtimisülesannete lahendamisel täita kindlad nõudmised, millest tähtsamad on järgmised: terviklikkus; perspektiivsus; eetilisus; säästlikkus; optimaalsus. Jätkusuutlikkuse käsitlustes ühiskonnaelu erinevatele allsüsteemidele esitatavad tingimused (standardid, normid, piirväärtused) annavad informatsiooni konkreetsete juhtimisülesannete struktureerimiseks. Need tingimused määratlevad optimeerimisülesannete piirangud, millega tuleb igal ühiskondlikul subjektil heaolu maksimeeriva arenguvariandi otsimisel arvestada. Jätkusuutlikkuse aspektist optimaalse arengustrateegia väljatöötamisel on mõttekas lähtuda otsustusteooria raames esitatud metodoloogilistest alustest.

Omaette probleemiks on määratleda näitajad, mille abil arengu jätkusuutlikkust iseloomustada ja analüüsida. Probleemiks ei ole mitte niivõrd jätkusuutlikkuse monitooringuks ja hindamiseks vajalike näitajate puudus, vaid just nende paljususest 
valiku tegemine ja vastastikuste seoste arvestamine. Rahvusvaheliselt on suureks väljakutseks on kõigi riikide jaoks ühtses näitajate kogumis kokkuleppele jõudmine.

Avatuse kiire suurenemine (globaliseerumine) tõstatas paljude nähtuste puhul arengu jätkusuutlikkuse probleemi seoses konkurentsi tugevnemisega. Seetõttu tuleb koosluste arengu jätkusuutlikkuse tagamisel eriti rõhutada konkurentsi arvestamise vajadust. Küsimus ei ole selles, kas mingi kooslus võiks mingis isoleeritud nišis või neutraalsetes välistingimustes edasi eksisteerida, vaid hinnata tuleb koosluse võimet püsima jääda eksistentsitingimuste pärast toimuvas vabas konkurentsis.

Konkurentsi (kui huvide vastandumise) seisukohalt määratledes väljendab jätkusuutlikkus vaatlusaluse koosluse positsiooni teiste koosluste suhtes hinnatuna mingist paremust või halvemust määravast omadusest või väliskeskkonna mõjurist määratud arengu tulemuse seisukohalt.

Vabas konkurentsis jätkusuutmatu koosluse säilitamiseks tuleb leida välise sekkumise otstarbekaim viis ja optimaalne ulatus. Välise sekkumise süsteemi loomisel peaks eesmärgiks olema koosluse arengu viimine tasemele, mis võimaldaks sellel vabas konkurentsis toime tulla.

Praktiliste juhtimisülesannete lahendamisel nõuab üldise ja abstraktse jätkusuutlikkuse kontseptsiooni rakendamine üleminekut globaalselt lähenemisviisilt lokaalsele ja subjektide huvide erinevuse arvestamist. See tähendab eri tasandite väljatoomist jätkusuutlikkuse käsitlustes. Käesolevas artiklis on eesmärgiks kohandada arengu jätkusuutlikkuse kontseptsioon konkreetse arenguülesande tasakaalustatud regionaalse arengu - lahendamise spetsiifilistele tingimustele.

Regionaalarengu jätkusuutlikkuse käsitluses on võtmetähtsusega regioonide arengutingimuste ja elanikkonna huvide spetsiifika arvestamine. Maailmast kui ühtsest tervikust lähtuvad arengu jätkusuutlikkuse käsitlused lähevad vastuollu regioonide objektiivsete erinevuste arvestamise vajadusega. Senini pole suudetud leida mõjusaid meetmeid maailma arengu regionaalse tasakaalustamatuse vähendamiseks.

Kokkuvõtlikult tähendab arengu jätkusuutlikkuse globaalkäsitluselt regionaalsele üleminek inimkonna kui terviku probleemide asendumist erinevate territoriaalsete üksuste elanikkonna elukeskkonna ja -tegevuse probleemidega. Terviku ja selle osade arenguprobleemide lahendamine nõuab kompleksset lähenemist: kohalike arenguinpulsside avamisele; kohalike arenguvõimaluste otsimisele; kohaliku infrastruktuuri arendamisele; konkurentsi mõjuga kohalikule arengule; regiooniüleste institutsioonide ülesannetele ja võimalustele regioonide omapära toetamisel ja regionaalse arengu tasakaalustamisel.

Regioon on arengu analüüsi aspektist spetsiifiline objekt, mis nõuab jätkusuutlikkuse kontseptsiooni kohandamist selle iseärasustega. Eelkõige tekivad probleemid globaalse kontseptsiooni rakendamisel lokaalselt, st terviku osade suhtes. 
Liikudes jätkusuutlikkuse käsitluses globaalselt tasandilt lokaalsele (majandusharu, regioon, ühiskonnakiht), muutuvad arengu juhtimise ülesanded üheltpoolt palju konkreetsemaks ja komplitseeritumaks. Teisalt ähmastub aga juhtimisülesannete lokaliseerimisel arengu jätkusuutlikkuse kontseptsiooni spetsiifika ja üha enam tõusevad ülesandepüstitustes esile tuttavad printsiibid, kontseptsioonid ja teooriad: konkurentsivõime kontseptsioon majanduses, õigluse printsiip sotsiaalsfääris, tasakaalustatuse nõue regionaalarengus, säästlik lähenemisviis looduskeskkonna ekspluateerimisel, demokraatia nõue poliitikas.

Regioon on sotsiaal-majanduslikus mõttes territoriaalne üksus, mille koosseisu kuuluvate subjektide suhted (koostöö, mõju, infovahetus) on omavahel intensiivsemad kui suhted regioonist väljapoole jäävate subjektidega. Seega on regiooni mõiste küllaltki avar.

Käesolevas töös võetakse regionaalsete üksuste eristamise aluseks administratiivne tunnus, sest:

- avaliku sektori suure osakaalu tõttu on suur ka administratiivsete institutsioonide roll ja vastutus erinevate subjektide koostöö organiseerimisel ja mõjutamisel,

- $\quad$ see tunnus on võrreldava olemuse ja mõjuga kogu riigi territooriumil,

- selle tunnuse alusel on regioonid üheselt piiritletud ja selgelt eristuvad,

- administratiivsete üksuste lõikes kogutakse ja töödeldakse regioone iseloomustav informatsioon.

Selgepiirilise regionaalse subjektina eristub ainult kohalik omavalitsus, kus regiooni asustava rahva poolt valitud volikogude otsuste alusel täitevaparaat tegutseb nende käsutuses oleva eelarve piires territoriaalse üksuse arengu suunamisega. Sellest lähtuvalt tuleb regionaalarengu jätkusuutlikkuse probleeme käsitleda Eestis peamiselt kohalike omavalitsusüksuste lõikes, kus konkreetsed institutsioonid tegelevad arengu analüüsi ja kavandamisega.

Riigi arengu jätkusuutlikkuse regionaalseid probleeme tuleks seega käsitleda järgnevast kolmest aspektist:

- mikroregioonide arengu jätkusuutlikkus;

- $\quad$ riigi mõju mikroregioonide arengu jätkusuutlikkusele;

- mikroregioonide mõju riigi arengu jätkusuutlikkusele.

Regioonide arengu jätkusuutlikkuse hindamine peamiste valdkondade lõikes: rahvastik, elu kvaliteet, tööturg, ettevõtlus, looduskeskkond. Regiooni arengu jätkusuutlikkusest ettekujutuse saamiseks lähtutakse selle valdkonna kirjanduses üldiselt tunnustatud dimensioonidest (sotsiaalne, majanduslik, ökoloogiline).

Ka Eesti arengu jätkusuutlikkuse rahvusvaheline esitlus rajaneb ühiskonnaelu kolmemõõtmelisel jaotusel (Estonian National ... 2002). Rõhutamaks jätkusuutlikkuse käsitluse inimkesksust käsitletakse sotsiaalset dimensiooni kolmes 
lõikes. Kõigepealt analüüsitakse rahvastikku, mis kujutab endast regiooni arengu kavandamisel nii lähtepunkti kui ka lõppeesmärki. Regioonis tegutsevad peamiselt seal elavad inimesed ja muutused viiakse ellu eelkõige nende inimeste elukvaliteedi parandamise eesmärgil. Rahvastikuanalüüsi järel tuleb seega käsitleda rahva elu kvaliteeti regioonis, mis iseloomustab üheltpoolt ajalooliselt saavutatud arengutaset ja teisalt tulevase arengu lähtebaasi. Tööturg ühendab inimese elukvaliteedi seda materiaalselt kindlustava majandustegevusega (ettevõtlusega) - sellest aspektist vaadatuna esineb inimene tööjõuna. Ettevõtluse analüüsi tulemusena saame hinnangu nii regiooni rahvastiku majanduslikule algatus-, organiseerimis- ja teostusvõimele kui ka regiooni ettevõtluskeskkonnale. Looduskeskkond varustab majandustegevust ressurssidega ja rahvastikku elamiskeskkonnaga, absorbeerides ja neutraliseerides samal ajal inimtegevuse tagajärgi. Seetõttu on keskkonnal arengu jätkusuutlikkuse hindamisel erakordne tähtsus.

Regiooni omavalitsuse ja keskvalitsuse ametkondade poolt avaldatav riigi mõju regiooni arengu jätkusuutlikkusele: regioonide haldussuutlikkus, avaliku sektori teenuste pakkumine regioonis, regiooni infrastruktuuri arengutase, riiklikud regionaalarengu programmid, ettevõtluse arendamise riiklikud programmid ja kohalikud abinõud, keskvalitsuse abi kohalikele omavalitsustele.

Regionaalse arengu soodustamiseks on kõigepealt tarvis leida haldusteenuste optimaalne jaotus keskvalitsuse ametkondade ja regionaalsete võimustruktuuride vahel. Seejärel kujuneb aga keskseks küsimuseks regionaalsete institutsioonide haldussuutlikkuse tagamine, mis peab toimuma peamiselt neile pandud ülesannete täitmise piisava rahastamise ja neile ülesannetele vastav ametnike koolitamise teel.

Regioonide arengutaseme mõju riigi arengule tuleneb: riigi regionaalse arengu tasakaalustatusest, majandusliku koostöö klastrite arengust. 